\section{Pollution Level Caused by the Effluents of Leather Industry and their Abatement}

Umme Habiba Bodrun Naher*, Mahamudul Hasan M and Farhad Ali M

Institute of Leather Engineering and Technology, University of Dhaka, Bangladesh

\begin{abstract}
This study concentrated on the physico-chemical characterization of effluents of leather industry and their reduction by filtration and coagulation processes as physical and chemical treatment. It was observed that the $\mathrm{pH}$ was basic and the TSS, TDS, $\mathrm{BOD}_{5}$ and $\mathrm{COD}$ were very high in the case of raw effluent. By adopting settling and filtration through glass wool, the effluents were somewhat treated. After that, chemical treatments were imposed upon them by using different doses of $\mathrm{FeCl}_{3}$ as coagulant and trimethyl ammonium chloride $\left[\left(\mathrm{CH}_{3}\right)_{3} \mathrm{NHCl}\right]$ as coagulant aid. It was observed that best result was found by using coagulant $\left(\mathrm{FeCl}_{3}\right)$ of $120 \mathrm{mg} / \mathrm{L}$ dose and coagulant aid $\left[\left(\mathrm{CH}_{3}\right)_{3} \mathrm{NHCl}\right] 12 \mathrm{mg} / \mathrm{L}$ dose near the neutral $\mathrm{pH}$. So, it could be said that tannery effluents would be treated by following a combination process of settling, filtering and coagulating with $\mathrm{FeCl}_{3}$ and $\left[\left(\mathrm{CH}_{3}\right)_{3} \mathrm{NHCl}\right.$.
\end{abstract}

Keywords: Pollutants; $\mathrm{BOD}_{5}$; COD; TSS; TDS; Effluents; Tannery

\section{Introduction}

Leather industry is one of the major earning sectors in Bangladesh. Bangladesh produces twenty million square meters of leather and leather products per year [1]. The leather is exported to some 70 countries throughout the world but predominantly in China, South Korea, Japan, Italy, Germany, Spain and The United States [2]. But at the same time, these leather tanning industries have been identified as one of the main causes of environmental pollution in the capital city of Dhaka of above 10 million people. In Bangladesh, there exists at present over 250 tanneries. Most of these are at Hazaribagh. There are 185 tanneries situated in this area [3]. Recently the area has been included at the list of top 10 most polluted places of the earth [4]. These tannery units during processing of raw hides and skins produce huge liquid wastages per day. The tanneries of Hazaribagh are liberating fat, and poisonous chemicals, lime, alkali, acids, bleaching agents, dyes, oils, hydrogen sulfide, heavy metals, etc. which are generally merged to the river of Buriganga without any action [5]. Generally tanneries of Bangladesh have no pollution control plant. This untreated liquor is discharged to drains and finally to nearby low lands, municipal sewers and rivers causing serious pollution to air, land and water and damaging land fertility as well as surface water system. Untreated tannery effluent also affects the local water supplies with various pollutants. The tanneries of Hazaribagh dump huge industrial wastes which are not treated simply by usual way [6]. Due to turbidity and colors, photosynthesis may be restricted affecting the primary link in food chain and aquatic life. However, the pollution load from the operating tanneries is contaminating the surface and ground water in the water quality of the river of Buriganga. $15800 \mathrm{~m}^{3} /$ day of dissipated water with a BOD of $17600 \mathrm{~kg} /$ day and high chromium concentration is ejected from the tanneries at Hazaribagh [7]. This problem deteriorates further in the dry seasons due to lower dilution factors. Effluents from conventional post tanning operations including chrome salts, syntans, dyestuffs, fat liquoring agents (fats/oils), pigments and organic matters are the main pollutants. In this research, the pollution level of tannery effluent is measured and compared to the standard level. It is also showed that pollution level can be controlled by following different treatment technology.

\section{Materials and Methods}

Effluents were collected from the laboratory of Institute of Leather Engineering and Technology during shoe upper leather processing from cow hide. Different parameters like $\mathrm{pH}$ were measured according to the method of SLC-120 [8]. COD, the test measures the amount of oxygen required for chemical oxidation of organic matter in the samples, was measured according to the method of DIN 38409. Again $\mathrm{BOD}_{5}$, a method based on oxidation of organic matter by suitable microorganism during a 5 days period was measured according to OXITOP measuring method. The total suspended solid (TSS) and total dissolved solid (TDS) were measured according to the methods of SLC-114 [9] and ASTM D 5907 respectively.

\section{Results and Discussion}

The collected tannery effluents were analyzed for determining the parameters named $\mathrm{pH}$, TSS, TDS, COD and $\mathrm{BOD}_{5}$. These parameters were measured and found as deviated from the standards. Most metals get soluble in water at low $\mathrm{pH}$ [10]. High amount of dissolved solid elements obstructs the density of water. Thus, it generates impact on osmoregulation of water and also lessens solubility of gasses [11]. The parameters of $\mathrm{pH}$, TSS, TDS, COD and $\mathrm{BOD}_{5}$ were found as $7.6,5800$ $\mathrm{mg} / \mathrm{L}, 10500 \mathrm{mg} / \mathrm{L}, 4260 \mathrm{mg} / \mathrm{L}$ and $820 \mathrm{mg} / \mathrm{L}$ respectively in untreated condition. The untreated tannery effluents were settled and then filtered gradually with glass wool and finally treated with Coagulant of $\mathrm{Fecl}_{3}$ $(\mathrm{mg} / \mathrm{L})$ and coagulant aid $\left[\left(\mathrm{CH}_{3}\right)_{3} \mathrm{NHCl}\right]$.

In case of glass wool treatment, the parameters of $\mathrm{pH}$, TSS, TDS, COD and $\mathrm{BOD}_{5}$ were found as $7.9,5700 \mathrm{mg} / \mathrm{L}, 9050 \mathrm{mg} / \mathrm{L}, 3500 \mathrm{mg} / \mathrm{L}$ and $760 \mathrm{mg} / \mathrm{L}$ respectively. Here the parameters are better than the previous one. High COD can be for the large amount of inorganic compounds which are not generally influenced by the bacterial corrosion [12]. High level of total suspended solid in water results poor photosynthetic system in the aquatic process and hampers respiratory method of fishes a lot [12]. Again, the effluents were then treated with Coagulant of $\mathrm{FeCl}_{3}(\mathrm{mg} / \mathrm{L})$ and coagulant aid $\left[\left(\mathrm{CH}_{3}\right)_{3} \mathrm{NHCl}\right]$ dose of $(40+4),(80+8)$ and $(120+12)$ respectively. Table 1 represents the values of the physicochemical parameters named $\mathrm{pH}$, TSS, TDS, COD and $\mathrm{BOD}_{5}$ of the untreated tannery effluents and after the treatment with glass wool filtration.

*Corresponding author: Umme Habiba Bodrun Naher, Institute of Leather Engineering and Technology, University of Dhaka, Bangladesh, Tel: +88029661900; E-mail: nahar_ilet@du.ac.bd

Received July 18, 2017; Accepted July 25, 2017; Published August 08, 2017

Citation: Naher UHB, Mahamudul Hasan M, Farhad Ali M (2017) Pollution Level Caused by the Effluents of Leather Industry and their Abatement. J Environ Anal Chem 4: 209. doi:10.41722380-2391.1000209

Copyright: @ 2017 Naher UHB, et al. This is an open-access article distributed under the terms of the Creative Commons Attribution License, which permits unrestricted use, distribution, and reproduction in any medium, provided the original author and source are credited. 
Citation: Naher UHB, Mahamudul Hasan M, Farhad Ali M (2017) Pollution Level Caused by the Effluents of Leather Industry and their Abatement. J Environ Anal Chem 4: 209. doi:10.41722380-2391.1000209

Page 2 of 2

Again, Table 2 represents these parameters of the effluents after being treated gradually with the Coagulant of $\mathrm{FeCl}_{3}(\mathrm{mg} / \mathrm{L})$ and coagulant aid $\left[\left(\mathrm{CH}_{3}\right)_{3} \mathrm{NHCl}\right](\mathrm{mg} / \mathrm{L})$ dose of $(40+4),(80+8)$ and $(120+12)$ respectively.

In case of the dose of $(40+4)$, the parameters of $\mathrm{pH}$, TSS, TDS, COD and $\mathrm{BOD}_{5}$ were found as $7.7,800 \mathrm{mg} / \mathrm{L}, 6200 \mathrm{mg} / \mathrm{L}, 1450 \mathrm{mg} / \mathrm{L}$ and $590 \mathrm{mg} / \mathrm{L}$ respectively. Then for the dose of $(80+8)$, these parameters were found as $7.3,540 \mathrm{mg} / \mathrm{L}, 5780 \mathrm{mg} / \mathrm{L}, 1180 \mathrm{mg} / \mathrm{L}$ and $480 \mathrm{mg} / \mathrm{L}$ respectively which are better than the previous. Again, the best values of the analysis of these physicochemical parameters were found for the dose of $(120+12)$. Here the values of these parameters of $\mathrm{pH}$, TSS, TDS, COD and $\mathrm{BOD}_{5}$ are $7.0,220 \mathrm{mg} / \mathrm{L}, 4230 \mathrm{mg} / \mathrm{L}, 400 \mathrm{mg} / \mathrm{L}$ and $180 \mathrm{mg} / \mathrm{L}$. With more coagulant doses these parameters are found in higher and nearer to the values of untreated form.

\section{Conclusion}

Leather industry has been facing a global challenge with respect to the ecological concern raised due to its waste streams. From the present observation it was observed that the tannery effluents possessed extremely high values of $\mathrm{pH}, \mathrm{TSS}$, TDS, $\mathrm{BOD}_{5}$ and $\mathrm{COD}$. The Values of these parameters were at a higher point than the standard values for ISW-BDS. For that reason, it is a great threat to human health and the environment to discharge the tannery effluent into surface water bodies. But it is a common scenario in Bangladesh that all the tanneries discharge their waste water directly or indirectly into the river without any treatment. This study makes clear that the filtration with glass wool reduce the pollution level to a certain extent. It is investigated that chemical treatment with using coagulant $\left(\mathrm{FeCl}_{3}\right)$ of $120 \mathrm{mg} / \mathrm{L}$ dose and coagulant aid trimethyl ammonium chloride $\left[\left(\mathrm{CH}_{3}\right)_{3} \mathrm{NHCl}\right] 12 \mathrm{mg} / \mathrm{L}$ dose showed the best results that were below the standard prescribed limit. The used coagulant and coagulant aid in this study are cost effective also. So it can be suggested that the tannery effluents can be treated by the combination processes of filtration and coagulation using coagulant and coagulant aid to reduce the pollution.

\section{Conflict of Interests}

The authors declare no conflict of interest.

\begin{tabular}{|c|c|c|c|}
\hline Parameters & $\begin{array}{c}\text { Untreated } \\
\text { Effluents }\end{array}$ & $\begin{array}{c}\text { Glass Wool Filtered } \\
\text { Effluents }\end{array}$ & Standards \\
\hline pH & 7.6 & 7.9 & $06-S e p$ \\
\hline TSS & 5800 & 5700 & $100(\mathrm{mg} / \mathrm{L})$ \\
\hline TDS & 10500 & 9050 & $2100(\mathrm{mg} / \mathrm{L})$ \\
\hline COD & 4260 & 3500 & $250 / 400(\mathrm{mg} / \mathrm{L})$ \\
\hline BOD $_{5}$ & 820 & 760 & $30 / 250(\mathrm{mg} / \mathrm{L})$ \\
\hline
\end{tabular}

Table 1: Physicochemical parameters ( $\mathrm{pH}, \mathrm{TSS}, \mathrm{TDS}, \mathrm{COD}$ and $\mathrm{BOD}_{5}$ ) of untreated tannery effluents after the filtration through glass wool and the standards.

\begin{tabular}{|c|c|c|c|}
\hline Parameters & $\begin{array}{c}\text { Coagulant Dose } \\
\text { of } \mathrm{FeCl}_{3}(\mathrm{mg} / \mathrm{L}) \\
\text { and } \mathrm{Coagulant} \\
\text { Aid }\left[\left(\mathrm{CH}_{3}\right)_{3} \mathrm{NHCl}\right] \\
(40+4)\end{array}$ & $\begin{array}{c}\text { Coagulant Dose } \\
\text { of } \mathrm{FeCl}_{3}(\mathrm{mg} / \mathrm{L}) \\
\text { and } \mathrm{Coagulant} \\
\left.\left.\text { Aid[( } \mathrm{CH}_{3}\right)_{3} \mathrm{NHCl}\right] \\
(80+8)\end{array}$ & $\begin{array}{c}\text { Coagulant Dose } \\
\text { of } \mathrm{FeCl}_{3}(\mathrm{mg} / \mathrm{L}) \\
\text { and } \mathrm{Coagulant} \\
\mathrm{Aid}\left[\left(\mathrm{CH}_{3}\right)_{3} \mathrm{NHCl}\right] \\
(120+12)\end{array}$ \\
\hline $\mathrm{pH}$ & 7.7 & 7.3 & 7 \\
\hline TSS & 800 & 540 & 220 \\
\hline TDS & 6200 & 5780 & 4230 \\
\hline COD & 1450 & 1180 & 400 \\
\hline $\mathrm{BOD}_{5}$ & 590 & 480 & 180 \\
\hline
\end{tabular}

Table 2: Physicochemical parameters $\left(\mathrm{pH}, \mathrm{TSS}, \mathrm{TDS}, \mathrm{COD}\right.$ and $\left.\mathrm{BOD}_{5}\right)$ treated with $\mathrm{FeCl}_{3}$ and coagulant aid $\left[\left(\mathrm{CH}_{3}\right)_{3} \mathrm{NHCl}\right]$

\section{References}

1. To Study Current Market Scenario and the Future Prospect of the Leather Chemical Industry of Bangladesh, Institute of Business Administration, University of Dhaka Report along with ACI Group.

2. Arantxa Cedillo for Human Watch (2012).

3. Ferdous Z, Akter S, Hasan M, Begum RA, Shahajahan RM (2012) Phytoplankton Diversity and Abundance in Relation to Pollution Levels in the Hazaribagh Tannery Effluent Sewage Water of the River Buriganga. Bangladesh J Zool 40: 121-128.

4. Blacksmith Institute, Switzerland (2013) The World's Worst the Top Ten Toxic Threats.

5. Chowdhury M, Mostafa MG, Kumar BT, Kumar SA (2013) Treatment of leather Industrial Effluent by filtration and coagulation processes. Elsevier Water Resource and Industry 3: 11-22.

6. Swathi M, Singh AS, Aravind SA, Ashisudhakar PK, Gobinath R, et al. (2014) Adsorption Studies on Tannery Wastewater Using Bamboo Dust as Absorbent. World Journal of Environmental Biosciences 3: 56-60.

7. Banani B, Takeshi H (2012) Industry Development and Buriganga River Pollution in Bangladesh 2: 117-127.

8. Society of leather Technologists and chemists, Official method of analysis (1996) Registered office: Edges Court, Moulton, Northampton, UK, pp: 87-88, 124-125, 128.

9. Jain RK, Rao SS (2006) Industrial Safety, Health and Environment Management System. Khanna Publishers. pp: 831-833.

10. Hossain MM, Baki MA (2015) Present Status of Preliminary Survey on Avifauna Diversity and Distribution in the Most Polluted River Buriganga, Dhaka, Bangladesh. International Journal of Pure and Applied Zoology 3: 59-69.

11. Azike RU, Odisu TU (2011) Monitoring of some flow-stations in the Niger Delta states of Nigeria Effluent. Journal of Environmental Science and Research Management, Vol: 3.

12. Akan Joseph C, Abdul Rahman Fanna I, Emmanuel Y (2010) Physics and chemical parameters in Abattoir wastewater sample, Maidulguri Metroplis, Nigeria. The Pacific Journal of Science and Technology, Vol: 11 